\title{
One Pot Conversion of Acetyl Chloride to Dehydroacetic Acid and its Coordination in a Ruthenium(II) Arene Complex
}

\author{
Lorenzo Biancalana, ${ }^{[\mathrm{a}]}$ Guido Pampaloni, ${ }^{[\mathrm{a}]}$ Stefano Zacchini, ${ }^{[\mathrm{b}]}$ Fabio Marchetti, ${ }^{[\mathrm{[a}]}$
}

${ }^{a}$ Dipartimento di Chimica e Chimica Industriale, Università di Pisa, Via G. Moruzzi 13, I-56124 Pisa, Italy.

${ }^{b}$ Dipartimento di Chimica Industriale "Toso Montanari”, Università di Bologna, Viale Risorgimento 4, I-40136 Bologna, Italy.

Received......; accepted

*Corresponding author: Prof. Fabio Marchetti.

Tel.: int. code 0502219245; E-mail address: fabio.marchetti1974@unipi.it

Webpage: https://people.unipi.it/fabio_marchetti1974/ 


\begin{abstract}
The reaction of $\left[\left(\eta^{6}-p\right.\right.$-cymene $) \mathrm{RuCl}\left(\kappa^{2} N, O\right.$-L-serinate $\left.)\right]$, 1, with $\mathrm{CH}_{3} \mathrm{C}(\mathrm{O}) \mathrm{Cl} / \mathrm{NEt}_{3}$, in chloroform at reflux temperature, led to the serendipitous isolation of the dehydroacetate complex $\left[\left(\eta^{6}-p-\right.\right.$ cymene $\left.\operatorname{RuCl}\left(\kappa^{2} O, O^{\prime}-\mathrm{dha}\right)\right], 2$, in low amount. Then, dehydroacetic acid (dhaH) was prepared in one pot by self condensation of acetyl chloride in the presence of $\mathrm{NEt}_{3}$ at room temperature, this reaction being unusual in the landscape of the chemistry of acyl chlorides. Complex 2 was synthesized in $89 \%$ yield from $\left[\left(\eta^{6}-p \text {-cymene }\right) \mathrm{RuCl}_{2}\right]_{2}$ and $\mathrm{dhaH}$, and fully characterized by means of $\mathrm{X}$-ray diffraction, IR and NMR spectroscopy. Complex 2 underwent fast and extensive dissociation of the dehydroacetate ligand in dmso/water solution, the degree of dissociation being substantially higher than that observed for the acetylacetonate ligand from $\left[\left(\eta^{6}-p\right.\right.$-cymene $) \mathrm{RuCl}\left(\kappa^{2} O, O^{\prime}\right.$-acac $\left.)\right], 3$.
\end{abstract}

Keywords: acyl chlorides; self condensation; dehydroacetic acid; ruthenium arene; X-ray diffraction. 


\section{Introduction}

Ruthenium(II) arene compounds have been intensively investigated for their anticancer properties [1] (Figure 1), and a common strategy aimed to enhance their cytotoxic activity consists in the incorporation of compounds with a known biological function [2]. A series of bioactive carboxylic acids have been introduced by esterification reaction of suitable ligands, these ligands being usually modified before coordination to the ruthenium centre [3]. However, the direct esterification of coordinated hydroxo-substituted triphenylphosphine [4] and tiophenolate [5] ligands has been also realized.

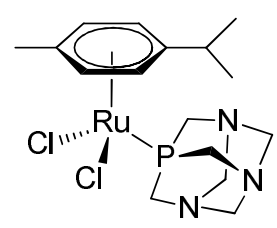

RAPTA-C

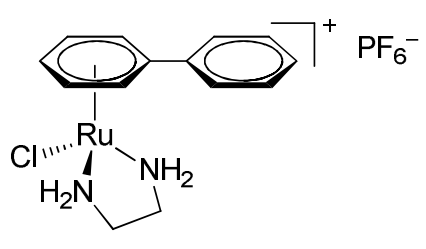

$\mathrm{RM}-175$

Figure 1. Most prominent anticancer ruthenium(II) arene compounds.

In this framework, we investigated the reaction of the complex $\left[\left(\eta^{6}-p\right.\right.$-cymene $) \mathrm{RuCl}\left(\kappa^{2} N, O-\mathrm{L}-\right.$ serinate)], 1 [6], containing a $\alpha$-amino acidate ligand with a hydroxyl group in the side chain, with acetyl chloride in the presence of triethylamine, as a model for esterification reactions. This reaction led to the serendipitous finding of the one pot conversion of acetyl chloride to dehydroacetic acid.

Dehydroacetic acid (dhaH, red compound in Scheme 1) and sodium dehydroacetate $(\mathrm{Na}[\mathrm{dha}])$ are commercially available chemicals, known for their antifungal and antibacterial activity [7]. Dehydroacetic acid is also a useful starting material for the preparation of heterocyclic compounds of biological interest, including the veterinary drug Clopidol [8]. Several synthetic procedures are available to access dhaH, making use of ethyl acetoacetate [9], dimethyl 3-oxoglutarate [10] or triacetic acid lactone [11] as precursors. On the industrial scale, dhaH is produced with the base-catalyzed dimerization of diketene. This is the product of the spontaneous $2+2$ cycloaddition of ketene (Scheme 
1d) [12], which in turn is usually obtained through gas-phase thermal decomposition of acetic acid or acetone (Scheme 1a-b) [13]. An alternative preparation of diketene (via ketene) from acetyl chloride has been reported too [14], finally affording diketene in $c a .50 \%$ yield after distillation from the reaction mixture (Scheme 1c).

(a)<smiles>CC(=O)OCCOCCO</smiles>

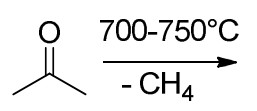

(b)

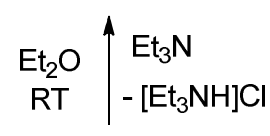

(c)

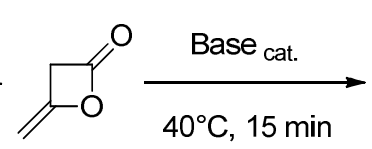<smiles>CC(=O)c1c(O)cc(C)oc1=O</smiles>

Base $=\mathrm{DABCO}, \mathrm{R}_{3} \mathrm{~N}, \mathrm{RONa}$

pyridine, imidazole<smiles>CC(=O)Cl</smiles>

Scheme 1. Preparation of dehydroacetic acid (dhaH) from C2-C3 feedstocks [15].

It should be remarked that the direct transformation of acetyl chloride to dhaH has not been reported heretofore. More in general, although acyl chlorides are versatile reagents hugely employed in organic and organometallic synthesis [16], self-condensation reactions of these substrates are not trivial tasks. To the best of our knowledge, the only conclusive report in the literature regards the synthesis of 4hydroxy-2-pyrones mediated by strong Lewis acids (e.g. $\mathrm{AlCl}_{3}$ ), via dehydroalogenative $\mathrm{C}-\mathrm{C}$ bond coupling [17]. Anyway, it should be noted that a poor level of regiochemical control may be observed under these conditions [18].

Herein, we describe the one pot self condensation reaction of acetyl chloride to dhaH promoted by triethylamine, and the incorporation of $\mathrm{dha}^{-}$as a bidentate ligand in a $\mathrm{Ru}(\mathrm{II}) p$-cymene complex. The structural characterization of this complex and the behavior in aqueous medium, investigated to assess the suitability to biological studies, will be discussed. 


\section{Results and discussion}

The reaction of the ruthenium(II) $p$-cymene $\alpha$-serinate complex 1 with an excess of $\mathrm{CH}_{3} \mathrm{COCl} / \mathrm{NEt}_{3}$ led to the isolation of few crystals of an orange solid after work-up. Surprisingly, the product was identified as the dehydroacetate complex 2 by X-ray single crystal diffraction and elemental analysis (Scheme 2).

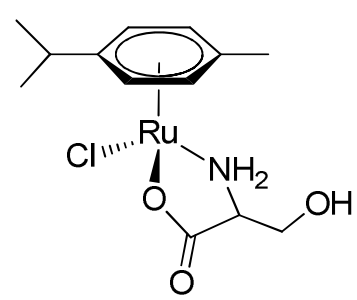

1

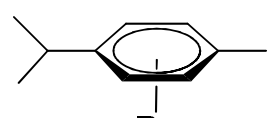<smiles>N[R1](=O)Cl</smiles><smiles>CC(=O)OCC(N)C(=O)O</smiles><smiles>Cc1ccc(C(C)C)cc1C</smiles>

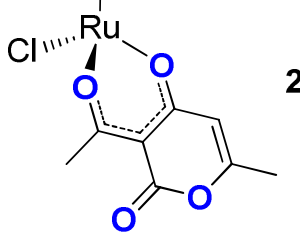

Scheme 2. Designed synthesis of $\left[\left(\eta^{6}-p\right.\right.$-cymene $\left.) \mathrm{RuCl}\left(\kappa^{2} \mathrm{~N}, \mathrm{O}-\mathrm{O}_{2} \mathrm{CCH}\left(\mathrm{NH}_{2}\right) \mathrm{CH}_{2} \mathrm{OCOCH}_{3}\right)\right]$, and serendipitous formation of $\left[\left(\eta^{6}-p\right.\right.$-cymene $\left.) \operatorname{RuCl}\left(\kappa^{2} O, O^{\prime}-\mathrm{dha}\right)\right], 2$.

A view of the ORTEP molecular structure of $\mathbf{2}$ is shown in Figure 2, while relevant bonding parameters are given in Table 1. 


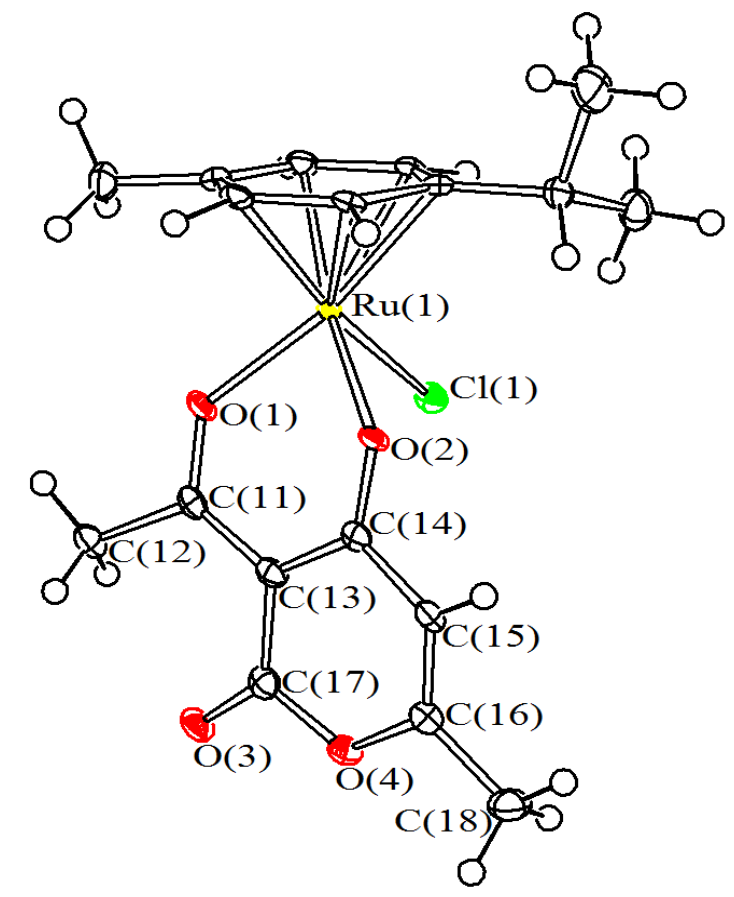

Figure 2. Molecular structure of $\left[\left(\eta^{6}-p\right.\right.$-cymene $\left.) \mathrm{RuCl}\left(\kappa^{2} O-\mathrm{OC}(\mathrm{Me}) \mathrm{CC}(\mathrm{O}) \mathrm{CHC}(\mathrm{Me}) \mathrm{OC}=\mathrm{O}\right)\right]$, 2. Displacement ellipsoids are at the $50 \%$ probability level.

Table 1.

Selected bond distances $(\AA)$ and angles $\left(^{\circ}\right)$ for 2 .

\begin{tabular}{llll}
\hline $\mathrm{Ru}(1)-\left(\eta^{6}-\mathrm{p}-\mathrm{cymene}\right)_{\mathrm{av}}$ & $2.178(7)$ & $\mathrm{Ru}(1)-\mathrm{Cl}(1)$ & $2.4112(9)$ \\
$\mathrm{Ru}(1)-\mathrm{O}(1)$ & $2.089(2)$ & $\mathrm{Ru}(1)-\mathrm{O}(2)$ & $2.079(2)$ \\
$\mathrm{C}(11)-\mathrm{O}(1)$ & $1.259(4)$ & $\mathrm{C}(14)-\mathrm{O}(2)$ & $1.280(4)$ \\
$\mathrm{C}(11)-\mathrm{C}(12)$ & $1.510(4)$ & $\mathrm{C}(11)-\mathrm{C}(13)$ & $1.440(5)$ \\
$\mathrm{C}(13)-\mathrm{C}(14)$ & $1.429(5)$ & $\mathrm{C}(13)-\mathrm{C}(17)$ & $1.446(5)$ \\
$\mathrm{C}(14)-\mathrm{C}(15)$ & $1.439(5)$ & $\mathrm{C}(15)-\mathrm{C}(16)$ & $1.337(5)$ \\
$\mathrm{C}(16)-\mathrm{C}(18)$ & $1.481(5)$ & $\mathrm{C}(16)-\mathrm{O}(4)$ & $1.369(4)$ \\
$\mathrm{C}(17)-\mathrm{O}(4)$ & $1.396(4)$ & $\mathrm{C}(17)-\mathrm{O}(3)$ & $1.217(4)$ \\
& & & \\
$\mathrm{O}(1)-\mathrm{Ru}(1)-\mathrm{O}(2)$ & $83.74(9)$ & $\mathrm{Ru}(1)-\mathrm{O}(1)-\mathrm{C}(11)$ & $130.1(2)$ \\
$\mathrm{Ru}(1)-\mathrm{O}(2)-\mathrm{C}(14)$ & $125.4(2)$ & $\mathrm{O}(1)-\mathrm{C}(11)-\mathrm{C}(13)$ & $123.6(3$ \\
$\mathrm{C}(11)-\mathrm{C}(13)-\mathrm{C}(14)$ & $121.6(3)$ & $\mathrm{C}(13)-\mathrm{C}(14)-\mathrm{O}(2)$ & $125.9(3)$ \\
$\mathrm{C}(13)-\mathrm{C}(14)-\mathrm{C}(15)$ & $117.8(3)$ & $\mathrm{C}(14)-\mathrm{C}(15)-\mathrm{C}(16)$ & $120.8(3)$ \\
$\mathrm{C}(15)-\mathrm{C}(16)-\mathrm{O}(4)$ & $121.6(3)$ & $\mathrm{C}(16)-\mathrm{O}(4)-\mathrm{C}(17)$ & $122.0(3)$ \\
$\mathrm{O}(4)-\mathrm{C}(17)-\mathrm{C}(13)$ & $117.6(3)$ & $\mathrm{C}(17)-\mathrm{C}(13)-\mathrm{C}(14)$ & $119.4(3)$ \\
\hline
\end{tabular}

Compound 2 comprises the expected three-leg piano-stool geometry typical of other Ru(II)-arene compounds, and the bonding parameters around the $\mathrm{Ru}(\mathrm{II})$ center are similar to those reported for 
related $\left[\mathrm{Ru}\left(\mathrm{O}^{\wedge} \mathrm{O}\right)(p\right.$-cymene $\left.) \mathrm{Cl}\right]$ structures $\left(\mathrm{O}^{\wedge} \mathrm{O}=\right.$ bidentate mono-anion with two $\mathrm{O}$-donor atoms $)$ $[2 \mathrm{~b}, \mathrm{~d}, 19]$.

The dehydroacetate anion is coordinated as a chelating $O, O^{\prime} \beta$-diketonate ligand, while the ester moiety is not involved in coordination. The same coordination fashion of $\mathrm{dha}^{-}$has been already observed in a variety of complexes with general formula $\left[\mathrm{M}^{(\mathrm{II})}(\mathrm{dha})_{2} \mathrm{~L}_{2}\right](\mathrm{M}=\mathrm{Cu}$ [20], Co [21], $\mathrm{Zn}$ [22], Cd [22], $\mathrm{Mn}$ [23], Ni [24]) or $\left[\mathrm{M}^{(\mathrm{III})} \mathrm{Cl}_{2}\right.$ (dha) $\left.\mathrm{L}_{2}\right]\left(\mathrm{M}=\mathrm{Ru}\right.$ [33], Re [25]). Bonding parameters within the dha ${ }^{-}$ligand in $\mathbf{2}$ are similar to those reported for the related complexes, showing a slightly shorter exocyclic $\mathrm{C}-\mathrm{O}$ bond $[\mathrm{C}(11)-\mathrm{O}(1) 1.259(4) \AA]$ within the $\beta$-diketonate moiety, compared to the endocyclic $\mathrm{C}-\mathrm{O}$ $[\mathrm{C}(14)-\mathrm{O}(2) 1.280(4) \AA]$. A reverse situation is observed for the $\mathrm{Ru}-\mathrm{O}$ bond distances $[\mathrm{Ru}(1)-\mathrm{O}(1)$ : 2.089(2) A; $\mathrm{Ru}(1)-\mathrm{O}(2): 2.079(2) \AA]$ ]. A comparison of bonding lengths is given in Table 2 concerning 2, dehydroacetic acid, sodium dehydroacetate and the previously reported complex $\left[\left(\eta^{6}-p\right.\right.$ cymene $) \operatorname{RuCl}\left(\kappa^{2} O, O^{\prime}\right.$-acac)], 3, differing from 2 in the presence of a symmetric $O, O^{\prime} \beta$-diketonate ligand (acetylacetonate).

\section{Table 2.}

Comparison of $\mathrm{C}-\mathrm{C}$ and $\mathrm{C}-\mathrm{O}$ bond distances in the $\beta$-diketonate moiety of dhaH, $\mathrm{Na}[\mathrm{dha}] \cdot \mathrm{H}_{2} \mathrm{O}$ and $\left[\left(\eta^{6}-p\right.\right.$ cymene $) \operatorname{RuCl}(\mathrm{L})](\mathrm{L}=$ acac, dha).

\begin{tabular}{|c|c|c|c|c|c|c|c|}
\hline \multirow{2}{*}{$\begin{array}{c}\text { Reference } \\
\text { structure }\end{array}$} & \multirow{2}{*}{ Compound } & \multicolumn{5}{|c|}{ Bond length / Å } & \multirow{2}{*}{ Ref. } \\
\hline & & $\mathrm{C}^{1}-\mathrm{O}^{1}$ & $C^{1}-C^{2}$ & $C^{2}-C^{3}$ & $C^{3}-O^{3}$ & $\mathrm{C}=\mathrm{O}$ lactone & \\
\hline \multirow{6}{*}{$\mathrm{H}_{3} \mathrm{C}^{-}$} & \multirow{2}{*}{ dhaH ${ }^{a}$} & $1.244(4)$ & $1.432(5)$ & $1.398(4)$ & $1.305(3)$ & $1.204(4)$ & \multirow{2}{*}[15b]{} \\
\hline & & $1.240(4)$ & $1.452(5)$ & $1.404(4)$ & $1.305(3)$ & $1.206(4)$ & \\
\hline & \multirow{2}{*}{$\mathrm{Na}[\mathrm{dha}] \cdot \mathrm{H}_{2} \mathrm{O}^{\mathrm{a}}$} & $1.222(4)$ & $1.448(4)$ & $1.437(4)$ & $1.253(3)$ & $1.210(4)$ & \multirow{2}{*}[26]{} \\
\hline & & $1.241(3)$ & $1.451(4)$ & $1.430(4)$ & $1.260(2)$ & $1.225(4)$ & \\
\hline & 2 & $1.259(4)$ & $1.440(5)$ & $1.429(5)$ & $1.280(4)$ & $1.217(4)$ & this work \\
\hline & 3 & $1.275(3)$ & $1.387(3)$ & $1.394(3)$ & $1.271(3)$ & - & {$[27]$} \\
\hline
\end{tabular}

\footnotetext{
a Two crystallographically-independent molecules in the asymmetric unit
} 
The serendipitous formation of $\mathbf{2}$ suggested a possible route to the one pot synthesis of dehydroacetic acid (dhaH) from acetyl chloride (Scheme 1). Therefore, despite dhaH is a low-cost, commercial product, we did an investigation to reproduce the synthesis of dhaH from $\mathrm{CH}_{3} \mathrm{COCl} / \mathrm{NEt}_{3}$.

An excess of triethylamine in chloroform was treated with acetyl chloride at room temperature, leading to the formation of dhaH (Scheme 3). Despite several byproducts were present in the crude reaction mixture, dhaH was isolated in $17 \%$ yield after dichloromethane/water extraction and silica chromatography. The formation of dhaH probably proceeds via (di)ketene, according to the known mechanism (see Introduction).

The direct acetyl chloride to dhaH conversion was found to be very sensitive to the experimental conditions, strictly requiring the use of dry triethylamine (stored over pre-activated MS-4A) in a dilute reaction mixture (see Experimental). It should be mentioned here that former studies on the ketene dimerization (polymerization) pointed that different self-condensation products could be generated, the presence of $\mathrm{H}_{2} \mathrm{O}$ traces being responsible for the formation of fused-ring systems [28]. The reactions of $\mathrm{CH}_{3} \mathrm{COCl}$ with $\mathrm{NEt}_{3}$, conducted in the presence of variable amounts of ruthenium(II) $p$-cymene compounds (1 or $\left.\left[\left(\eta^{6}-p \text {-cymene }\right) \mathrm{RuCl}_{2}\right]_{2}\right)$, did not result in any increase of yield/selectivity; this fact suggests that ruthenium does not probably participate to the formation of dhaH, even though it may stabilize the anion $\mathrm{dha}^{-}$by coordination (formation of $\mathbf{2}$, Scheme 2 ).

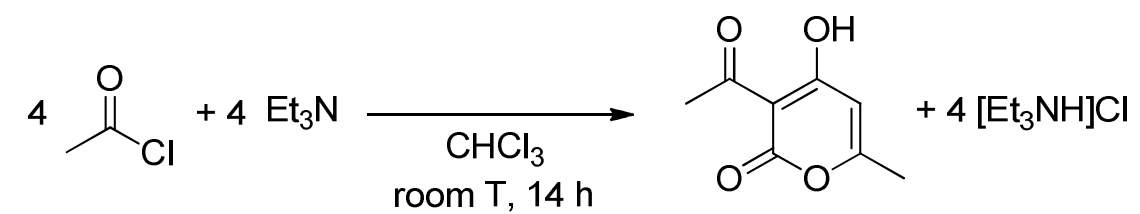

Scheme 3. One-pot synthesis of dehydroacetic acid (dhaH) from acetyl chloride and triethylamine.

In order to obtain larger amounts of 2 for full characterization, the reaction between $\left[\left(\eta^{6}-p\right.\right.$ cymene) $\left.\mathrm{RuCl}_{2}\right]_{2}$ and dhaH was performed in methanol at room temperature in the presence of $\mathrm{NaOH}$. 
Thus, 2 was finally isolated as a yellow-brown solid in $89 \%$ yield and then characterized by analytical and spectroscopic (IR/NMR) techniques. A comparative view of IR and NMR data for $\mathbf{2}$ and related compounds is supplied in Table 3.

Compound 2 is a racemate in $\mathrm{CDCl}_{3}$ solution, containing a stereogenic $\mathrm{Ru}$ center. As a consequence, distinct resonances for otherwise equivalent isopropyl/methyl groups of the $p$-cymene ligand can be found in the ${ }^{1} \mathrm{H}$ and ${ }^{13} \mathrm{C}$ NMR spectra. In the ${ }^{1} \mathrm{H}$ spectrum of 2 , the dha ${ }^{-}$ligand gives rise to three singlets at 5.80, 2.59 and $2.15 \mathrm{ppm}$, assigned to the vinyl proton and the two methyl groups, respectively. In the ${ }^{13} \mathrm{C}$ spectrum, the $\beta$-diketonate moiety is featured by resonances at $196.7,180.6$ and $101.9 \mathrm{ppm}$, while the lactone resonance has been found at $163.8 \mathrm{ppm}$. These chemical shift values are reminiscent of those of sodium dehydroacetate.

The IR spectrum of dehydroacetic acid shows four strong bands in the $1700-1500 \mathrm{~cm}^{-1}$ region, due to the stretching of the ketone $\left(1730 \mathrm{~cm}^{-1}\right)$ and lactone $\left(1708 \mathrm{~cm}^{-1}\right)$ carbonyls and two $\mathrm{C}=\mathrm{C}$ stretching of the aromatic system $\left(1638\right.$ and $\left.1547 \mathrm{~cm}^{-1}\right)$. In the IR spectrum of 2 (solid state), two strong bands at 1650 and $1567 \mathrm{~cm}^{-1}$ have been attributed to the $v(\mathrm{C}-\mathrm{C}-\mathrm{O})$ stretchings of the $\beta$-diketonate ligand. As a comparison, the corresponding absorptions fall at 1574 and $1521 \mathrm{~cm}^{-1}$ in the IR spectrum of 3 . The lactone stretching in 2 occurs at $1694 \mathrm{~cm}^{-1}$, showing minor variation with respect to non-coordinated dhaH.

Table 3.

Comparison of selected IR and NMR data for $\mathbf{2}, \mathbf{3}$, dhaH and $\mathrm{Na}[\mathrm{dha}]$.

\begin{tabular}{|c|c|c|c|c|c|c|c|c|}
\hline \multirow{2}{*}{ Compound } & \multicolumn{4}{|c|}{ IR (solid state) : $\tilde{v} / \mathbf{c m}^{-1}$} & \multicolumn{2}{|c|}{$\begin{array}{c}{ }^{13} \mathrm{C} \mathrm{NMR}\left(\mathrm{CDCl}_{3}\right): \\
\delta / \mathrm{ppm}\end{array}$} & \multicolumn{2}{|c|}{$\begin{array}{c}{ }^{1} \mathrm{H} \text { NMR }\left(\mathrm{CDCl}_{3}\right): \\
\delta / p p m\end{array}$} \\
\hline & $\begin{array}{l}\mathrm{v}(\mathrm{C}=\mathrm{O}) \\
\text { lactone }\end{array}$ & $\begin{array}{r}v(C-C \\
\text { 1,2-dike }\end{array}$ & $\begin{array}{l}\text { O) } \\
\text { nate }\end{array}$ & $v(C=C)$ & $\begin{array}{c}\mathrm{CO}_{2} \\
\text { lactone }\end{array}$ & $\begin{array}{c}\text { 1,2-diketo } \\
\text { moiety }\end{array}$ & $\mathrm{CH}_{3}-\mathrm{C}=\mathrm{O}$ & $\mathrm{H}-\mathrm{C}=\mathrm{C}$ \\
\hline dhaH $^{a}$ & $1708 \mathrm{~s}$ & $1730 s^{-s h}{ }^{b}$ & $1638 \mathrm{~s}^{\mathrm{b}}$ & $1547 \mathrm{~s}$ & 161.4 & $\begin{array}{c}205.4,181.2 \\
100.0\end{array}$ & 2.66 & 5.93 \\
\hline $\mathbf{N a}\left[\right.$ dha] ${ }^{c}$ & $1676 \mathrm{~s}$ & $1659 \mathrm{~s}$ & $1604 \mathrm{~s}$ & $1538 \mathrm{~s}$ & 159.1 & $\begin{array}{c}196.7,181.0 \\
102.3\end{array}$ & 2.30 & 5.44 \\
\hline 2 & $1694 \mathrm{~s}$ & $1650 \mathrm{~s}$ & $1567 \mathrm{~s}$ & $1567 \mathrm{~s}$ & 163.8 & $\begin{array}{c}197.6,180.6 \\
101.9\end{array}$ & 2.59 & 5.80 \\
\hline $3^{d}$ & - & $1574 \mathrm{~s}$ & $1521 \mathrm{~s}$ & - & - & $186.4,98.7$ & 1.96 & - \\
\hline
\end{tabular}




\section{Reference structures and}

color code

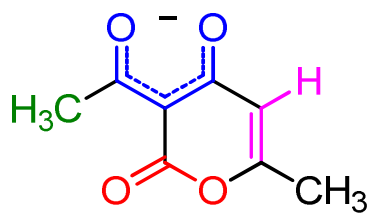<smiles>CC(=O)C=CC(C)=O</smiles>

${ }^{a}$ IR assignments from ref. [29]. ${ }^{b}$ Corresponding to $v(\mathrm{C}=\mathrm{O})$ and $v(\mathrm{C}=\mathrm{C})$ in the $\alpha$-ketoenol structure of dhaH (see Scheme 1 , red compound). ${ }^{\mathrm{c}} \mathrm{NMR}$ data in DMSO-d 6 from ref. [30]. ${ }^{\mathrm{d} 13} \mathrm{C}$ NMR data from ref. [43a].

In the light of the biological properties of dehydroacetic acid (see Introduction), a number of dehydroacetate metal complexes have been investigated for their possible biological applications [31]. In particular, $\mathrm{Cu}$ (II) [32], $\mathrm{Ru}(\mathrm{II})$ [33], $\mathrm{Zn}$ (II) and $\mathrm{Sn}$ (II) [34] compounds have been demonstrated to exhibit antifungal, antimicrobial or antibacterial activity, the activity being sometimes enhanced compared to that of dhaH itself. It should be noticed also that structurally-related pyrones have been conjugated to $\mathrm{Pt}(\mathrm{II})$ or $\mathrm{Ru}(\mathrm{II})$ arene scaffolds with the aim of obtaining a synergic effect in terms of anticancer activity [35].

In order to assess the suitability of $\mathbf{2}$ to cytotoxicity studies, we investigated the stability of this compound in aqueous medium at $37^{\circ} \mathrm{C}$ along $72 \mathrm{~h}$. Due to insolubility in water, the stability of 2 was evaluated by ${ }^{1} \mathrm{H}$ NMR in a DMSO: $\mathrm{D}_{2} \mathrm{O}$ 9:1 v/v solution, being DMSO a solvent of choice in drug research [36]. $\mathrm{NaCl} 0.11 \mathrm{M}$ was added to the solution, thus matching the chloride concentration normally employed for in vitro tests. Under these conditions, rapid release of dha ${ }^{-}$from 2 took place, with only minor amounts $(<10 \%)$ of the starting material still in solution from $7 \mathrm{~h}$ onwards (see Scheme 4 and Table 4). On the other hand, the analogous acetylacetonate compound 3 resulted significantly more inert toward ligand dissociation, as $c a$. 70\% of Ru-acac persisted in solution after 72 h (see Scheme 5 and Table 5).

Scheme 4 and Table 4. NMR detected species as a function of time in the dmso/ $\mathrm{H}_{2} \mathrm{O} / \mathrm{NaCl}$ solution of 2 at $37^{\circ} \mathrm{C}$. 


time / hours
2 vs. internal standard

Scheme 5 and Table 5. NMR detected species as a function of time in the dmso/ $\mathrm{H}_{2} \mathrm{O} / \mathrm{NaCl}$ solution of 3 at $37^{\circ} \mathrm{C}$.

\begin{tabular}{c|ccccccc}
3 \\
3
\end{tabular}

Earlier studies on the behavior of ruthenium arene complexes in aqueous solution evidenced that N,Nand N,O-bidentate ligands usually remained bound to the metal centre [1f, 37]. In contrast with this general trend, a significant release over time has been reported for a variety of O,O-ligands, including fluoro-substituted diketonates [38], quinolones [19a], maltolate [39] and 3-hydroxy-4-pyr(id)ones [35]. For instance, ca. $40 \%$ release of quinolone ligands was detected after $24 \mathrm{~h}$ in aqueous solution. It is 
noteworthy that a high degree of dissociation may correlate with a low cytotoxicity against a panel of cancer cell lines [35]. On account of these considerations, we decided not to proceed with biological assays on compound $\mathbf{2}$.

\section{Conclusions}

In the course of our studies on the structural modification of $\mathrm{Ru}(\mathrm{II})$ arene complexes for medicinal purposes, we have serendipitously found that acetyl chloride can be converted into dehydroacetic acid in one pot, in the presence of triethylamine. This reaction, albeit occurring in low yield, represents an unusual case of acyl chloride self condensation. $\mathrm{A} \mathrm{Ru}(\mathrm{II})$ arene - dehydroacetate conjugate has been prepared and structurally characterized. This compound manifests fast and extensive release of the bidentate $\mathrm{O}, \mathrm{O}-$ ligand in aqueous medium, the degree of dissociation being superior to that exhibited by acetylacetonate in an analogous system. This observation resembles previous reports on the relative lability, in aqueous environment, of various bidentate $\mathrm{O}, \mathrm{O}$-donors coordinated to $\mathrm{Ru}(\mathrm{II})$ arene complexes. 


\section{Experimental}

\subsection{General experimental details.}

$\mathrm{RuCl}_{3} \cdot \mathrm{xH}_{2} \mathrm{O}(99.9 \%)$ was purchased from Alfa Aesar, then $\left[\left(\eta^{6}-p \text {-cymene }\right) \mathrm{RuCl}_{2}\right]_{2}[40]$ and $\left[\left(\eta^{6}-p\right.\right.$ cymene)RuCl( $\kappa^{2} N, O$-L-serinate) $], 1[6]$, were prepared according to the literature. The organic reactants and solvents were obtained from Alfa Aesar, Sigma Aldrich or TCI Europe, and were of the highest purity available. Acetyl chloride and $\mathrm{Et}_{3} \mathrm{~N}$ (over $4 \AA \mathrm{MS}$ ) were stored under nitrogen as received. 1.0 M NaOH solution in water was prepared from Normex solution (Carlo Erba) and standardized by potassium hydrogen phthalate titration before use. The synthesis of dehydroacetic acid $(\mathrm{dhaH})$ and the reaction of $\mathbf{1}$ with $\mathrm{MeCOCl} / \mathrm{Et}_{3} \mathrm{~N}$ were performed under a nitrogen atmosphere using standard Schlenk techniques and solvents distilled from appropriate drying agents. All the other operations were carried out in air with common laboratory glassware. NMR spectra were recorded at $298 \mathrm{~K}$ on a Bruker Avance II DRX400 instrument equipped with a BBFO broadband probe. Chemical shifts (expressed in parts per million) are referenced to the residual solvent peaks $\left({ }^{1} \mathrm{H},{ }^{13} \mathrm{C}\right)[41]$. Spectra were assigned with the assistance of DEPT- $135,{ }^{1} \mathrm{H}^{-1} \mathrm{H}(\mathrm{COSY})$ and ${ }^{1} \mathrm{H}_{-}{ }^{13} \mathrm{C}\left(g s-\mathrm{HSQC}\right.$ and $g S^{-}$ HMBC) correlation experiments [42]. Infrared spectra were recorded on a Perkin Elmer Spectrum One FT-IR spectrometer, equipped with a UATR sampling accessory. Carbon, hydrogen and nitrogen analyses were performed on a Carlo Erba mod. 1106 instrument.

\subsection{Synthesis and characterization of compounds.}

\subsubsection{Reaction of [( $\eta^{6}-p$-cymene $) \mathrm{RuCl}\left(\kappa^{2} \mathrm{~N}, \mathrm{O}\right.$-L-serinate $\left.)\right]$, 1, with $\mathrm{CH}_{3} \mathrm{C}(\mathrm{O}) \mathrm{Cl} / \mathrm{NEt}_{3}$.}

In a $25-\mathrm{mL}$ Schlenk tube, $\mathrm{Et}_{3} \mathrm{~N}(1.1 \mathrm{~mL}, 7.9 \mathrm{mmol})$ was added to a mixture of $1(58 \mathrm{mg}, 0.16 \mathrm{mmol})$ and acetyl chloride $(55 \mu \mathrm{L}, 0.77 \mathrm{mmol})$ in $\mathrm{CHCl}_{3}(8 \mathrm{~mL})$. The resulting yellow solution was stirred at reflux temperature for 4 hours then at room temperature overnight. The mixture was then extracted with $\mathrm{H}_{2} \mathrm{O}(3 \times 15 \mathrm{~mL})$ and volatiles were removed under vacuum from the organic phase, affording a 
yellow-orange solid. X-ray quality crystals of 2 were collected from a $\mathrm{CHCl}_{3}$ solution of this solid layered with hexane and settled aside at $-20^{\circ} \mathrm{C}$. Anal. Calcd. for $\mathrm{C}_{18} \mathrm{H}_{21} \mathrm{ClO}_{4} \mathrm{Ru}$ : $\mathrm{C}, 49.37 ; \mathrm{H}, 4.83$. Found: C, 4; 49.84, 4.70 .

\subsubsection{Dehydroacetic acid (dhaH).}

In a $25-\mathrm{mL}$ Schlenk tube, acetyl chloride $(0.10 \mathrm{~mL}, 1.4 \mathrm{mmol})$ was added dropwise to a solution of $\mathrm{Et}_{3} \mathrm{~N}(0.40 \mathrm{~mL}, 2.9 \mathrm{mmol})$ in $\mathrm{CHCl}_{3}(9 \mathrm{~mL})$ and the resulting colorless solution $\left(\mathrm{c}_{\mathrm{MeCOCl}}=0.15 \mathrm{~mol} \cdot \mathrm{L}^{-}\right.$ ${ }^{1}$ ) was stirred at room temperature for 15 hours. A pale yellow solution was obtained, thus volatiles were removed under vacuum and the residue was re-dissolved in $\mathrm{CH}_{2} \mathrm{Cl}_{2}$. The organic phase was extracted with $\mathrm{H}_{2} \mathrm{O}(\mathrm{x} 3)$ and then loaded on top of a silica column. The title compound was obtained as a colorless solid following elution with EtOAc:hexane 2:1 v/v and solvent removal under vacuum $\left(40^{\circ} \mathrm{C}\right)$. Yield: $11 \mathrm{mg}, 19 \%$. Anal. Calcd. for $\mathrm{C}_{8} \mathrm{H}_{8} \mathrm{O}_{4}: \mathrm{C}, 57.14 ; \mathrm{H}, 4.79$. Found: $\mathrm{C}, 57.22 ; \mathrm{H}, 4.65$. IR (solid state): $\tilde{v} / \mathrm{cm}^{-1}=3087 \mathrm{w}, 2962 \mathrm{w}, 2927 \mathrm{w}, 1730 \mathrm{~s}-\mathrm{sh}\left(v_{\mathrm{C} 7=\mathrm{O}}\right), 1708 \mathrm{~s}\left(v_{\mathrm{C} 5=\mathrm{O}}\right), 1638 \mathrm{~s}\left(v_{\mathrm{C} 1=\mathrm{C} 6}\right), 1611 \mathrm{~m}-$ $\mathrm{sh}, 1547 \mathrm{~s}\left(v_{\mathrm{C} 2}=\mathrm{C} 3\right), 1449 \mathrm{~m}, 1429 \mathrm{~m}-\mathrm{sh}, 1416 \mathrm{~m}-\mathrm{sh}, 1371 \mathrm{~m}, 1349 \mathrm{~m}, 1254 \mathrm{~s}, 1170 \mathrm{w}, 1031 \mathrm{~m}, 1008 \mathrm{~m}-\mathrm{sh}$, 995s, 963m, 923m, 856s, 806w, 778m, 711w, 704w. ${ }^{1} \mathrm{H}$ NMR $\left(\mathrm{CDCl}_{3}\right): \delta / \mathrm{ppm}=16.69(\mathrm{~s}, 1 \mathrm{H}, \mathrm{OH})$, 5.93 (s, 1H, C2-H), 2.66 (s, 3H, C8-H), 2.27 (s, 3H, C4-H). ${ }^{13} \mathrm{C}\left\{{ }^{1} \mathrm{H}\right\}$ NMR $\left(\mathrm{CDCl}_{3}\right): \delta / \mathrm{ppm}=205.4$ (C7), 181.2 (C1), 169.2 (C3), 161.4 (C5), 101.6 (C2), 100.0 (C6), 30.2 (C8), 20.8 (C4).

A comparable yield of dhaH was obtained when the reaction was performed under protection from the light or with 10 eq. of $\mathrm{Et}_{3} \mathrm{~N}$. The development of a red color with massive precipitation of $\left[\mathrm{NEt}_{3} \mathrm{H}\right] \mathrm{Cl}$ was observed when the reaction was performed in more concentrated solutions $\left(\mathrm{c}_{\mathrm{MeCOCl}}=0.5,1.0\right.$ $\left.\mathrm{mol} \cdot \mathrm{L}^{-1}\right)$. In these cases, no dhaH was identified in the crude reaction mixture by ${ }^{1} \mathrm{H}$ NMR. When the reaction was performed with $\mathrm{c}_{\mathrm{MeCOCl}}=0.5 \mathrm{~mol} \cdot \mathrm{L}^{-1}$ at $0^{\circ} \mathrm{C}$, a yellow solution not containing dhaH was obtained. 
<smiles>CC(=O)c1c(O)cc(C)oc1=O</smiles>

Chart 1. Structure of dhaH (numbering refers to carbon atoms). [15]

\subsection{3. $\left[\left(\eta^{6}-p\right.\right.$-cymene $\left.) \operatorname{RuCl}\left(\kappa^{2} O, O^{\prime}-d h a\right)\right], 2$.}

A brick red solution of $\left[\left(\eta^{6}-p \text {-cymene }\right) \mathrm{RuCl}_{2}\right]_{2}(302 \mathrm{mg}, 0.493 \mathrm{mmol})$ and dhaH $(167 \mathrm{mg}, 0.993 \mathrm{mmol})$ in $\mathrm{MeOH}(20 \mathrm{~mL})$ was treated with $1.0 \mathrm{M} \mathrm{NaOH}(1.0 \mathrm{~mL}, 1.0 \mathrm{mmol})$. The resulting yellow-orange solution was stirred at room temperature overnight, therefore volatiles were removed under vacuum. The residue was suspended in $\mathrm{CH}_{2} \mathrm{Cl}_{2}$ and filtered. The filtrate solution was taken to dryness under vacuum affording a yellow-brown solid, which was washed with hexane and dried under vacuum $\left(50^{\circ} \mathrm{C}\right)$. Yield: $396 \mathrm{mg}, 89 \%$. Compound 2 is soluble in $\mathrm{DMSO}, \mathrm{MeOH}$ and $\mathrm{CH}_{2} \mathrm{Cl}_{2}$, poorly soluble in $\mathrm{Et}_{2} \mathrm{O}$ and insoluble in hexane and $\mathrm{H}_{2} \mathrm{O}$. Anal. Calcd. for $\mathrm{C}_{18} \mathrm{H}_{21} \mathrm{ClO}_{4} \mathrm{Ru}: \mathrm{C}, 49.37 ; \mathrm{H}, 4.83$. Found: $\mathrm{C}$, 49.22; H, 4.75. IR (solid state): $\tilde{v} / \mathrm{cm}^{-1}=3062 \mathrm{w}, 3002 \mathrm{w}, 2961 \mathrm{w}, 2922 \mathrm{w}, 2869 \mathrm{w}, 1694 \mathrm{~s}\left(v_{\mathrm{C} 12=\mathrm{O}}\right), 1650 \mathrm{~s}$ $\left(v_{\mathrm{C} 13-\mathrm{C} 14-\mathrm{O}}\right), 1567 \mathrm{~s}\left(v_{\mathrm{C} 13-\mathrm{C} 8-\mathrm{O}}+v_{\mathrm{C} 9=\mathrm{C} 10}\right), 1471 \mathrm{~s}, 1421 \mathrm{~s}, 1396 \mathrm{~s}, 1378 \mathrm{~s}, 1363 \mathrm{~s}, 1349 \mathrm{~s}, 1280 \mathrm{w}, 1264 \mathrm{w}$, $1238 \mathrm{~m}, 1201 \mathrm{w}, 1165 \mathrm{~m}, 1114 \mathrm{w}, 1092 \mathrm{w}, 1066 \mathrm{~m}, 1056 \mathrm{w}-\mathrm{sh}, 1033 \mathrm{~m}, 1023 \mathrm{w}-\mathrm{sh}, 1003 \mathrm{~m}, 970 \mathrm{~m}, 947 \mathrm{~m}$, 882m, 844m, 806w, 780m, 728w, 718w, 687w, 668w. ${ }^{1} \mathrm{H}$ NMR $\left(\mathrm{CDCl}_{3}\right): \delta / \mathrm{ppm}=5.80(\mathrm{~s}, 1 \mathrm{H}, \mathrm{C} 9-\mathrm{H})$, 5.53 (pseudo-t, $\left.{ }^{3} J_{\mathrm{HH}}=5.0 \mathrm{~Hz}, 2 \mathrm{H}, \mathrm{C} 4-\mathrm{H}+\mathrm{C} 4{ }^{\prime}-\mathrm{H}\right), 5.27\left(\mathrm{~d},{ }^{3} J_{\mathrm{HH}}=6.0 \mathrm{~Hz}, 2 \mathrm{H}, \mathrm{C} 3-\mathrm{H}+\mathrm{C} 3{ }^{\prime}-\mathrm{H}\right), 2.89$ (hept, $\left.{ }^{3} J_{\mathrm{HH}}=7.0 \mathrm{~Hz}, 1 \mathrm{H}, \mathrm{C} 6-\mathrm{H}\right), 2.59(\mathrm{~s}, 3 \mathrm{H}, \mathrm{C} 15-\mathrm{H}), 2.24$ (s, 3H, C1-H), 2.04 (s, 3H, C11-H), 1.33 (d, $\left.{ }^{3} J_{\mathrm{HH}}=6.9 \mathrm{~Hz}, 6 \mathrm{H}, \mathrm{C} 7-\mathrm{H}+\mathrm{C} 7{ }^{\prime}-\mathrm{H}\right) .{ }^{13} \mathrm{C}\left\{{ }^{1} \mathrm{H}\right\} \mathrm{NMR}\left(\mathrm{CDCl}_{3}\right): \delta / \mathrm{ppm}=197.6(\mathrm{C} 14), 180.6(\mathrm{C} 8), 163.8$ (C12), 163.4 (C10), 106.5 (C9), 101.9 (C13), 100.2 (C5), 97.4 (C2), 82.8, 82.6 (C4 + C4'), 79.5, 79.5 (C3 + C3'), 31.9 (C15), 30.9 (C6), 22.4, 22.3 (C7 + C7'), 19.9 (C11), $18.0(\mathrm{C} 1)$. A clean recovery of the starting materials was obtained when the reaction was performed in refluxing $\mathrm{CH}_{2} \mathrm{Cl}_{2}$ without the addition of a base. 

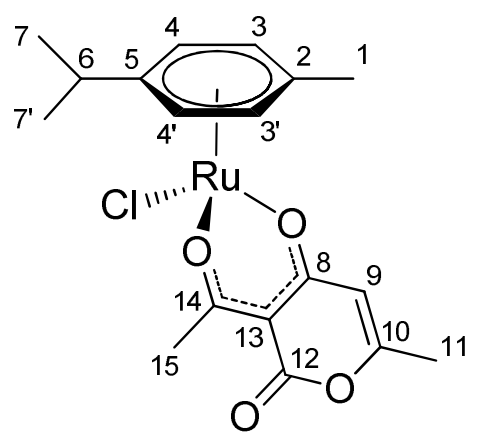

Chart 2. Structure of $\left[\left(\eta^{6}-p\right.\right.$-cymene) $\mathrm{RuCl}\left(\kappa^{2} O, O^{\prime}\right.$-dha) $)$, 2 (numbering refers to carbon atoms).

\subsubsection{Sodium dehydroacetate monohydrate, $\mathrm{Na}[\mathrm{dha}] \cdot \mathrm{H}_{2} \mathrm{O}$.}

$\mathrm{NaOH}(1.0 \mathrm{M}, 0.64 \mathrm{~mL}, 0.64 \mathrm{mmol})$ was added dropwise to a suspension of dhaH (107 $\mathrm{mg}, 0.636$ $\mathrm{mmol})$ in water $(3 \mathrm{~mL})$. The resulting pale yellow solution $(\mathrm{pH}=8)$ was stirred at room temperature for 2.5 hours. Therefore volatiles were removed under vacuum and the residue was suspended in $\mathrm{Et}_{2} \mathrm{O}$. The suspension was filtered and the resulting colorless solid was washed with $\mathrm{Et}_{2} \mathrm{O}$ and dried under vacuum $\left(40^{\circ} \mathrm{C}\right)$. Yield: $123 \mathrm{mg}, 93 \%$. Anal. Calcd. for $\mathrm{C}_{8} \mathrm{H}_{9} \mathrm{NaO}_{5}$ : C, 46.16; H, 4.36. Found: $\mathrm{C}, 46.30 ; \mathrm{H}, 4.29$. IR (solid state): $\tilde{v} / \mathrm{cm}^{-1}=3400 \mathrm{w}-\mathrm{br}\left(v_{\mathrm{OH}}\right), 3077 \mathrm{w}, 2994 \mathrm{w}, 2965 \mathrm{w}, 2927 \mathrm{w}, 1711 \mathrm{~m}-\mathrm{sh}, 1676 \mathrm{~s}\left(v_{\mathrm{C} 5=\mathrm{O}}\right)$, $1659 \mathrm{~s}\left(v_{\mathrm{C} 6-\mathrm{C} 7-\mathrm{O}}\right), 1604 \mathrm{~s}\left(v_{\mathrm{C} 6-\mathrm{C} 1-\mathrm{O}}\right), 1538 \mathrm{~s}\left(v_{\mathrm{C} 2=\mathrm{C} 3}\right), 1444 \mathrm{~m}-\mathrm{sh}, 1401 \mathrm{~s}, 1382 \mathrm{~s}-\mathrm{sh}, 1358 \mathrm{~s}, 1343 \mathrm{~s}, 1263 \mathrm{~m}$, $1221 \mathrm{w}, 1203 \mathrm{w}, 1165 \mathrm{~m}, 1112 \mathrm{w}, 1061 \mathrm{w}, 1022 \mathrm{~m}, 1000 \mathrm{~s}, 952 \mathrm{~m}, 898 \mathrm{~m}, 833 \mathrm{~m}, 776 \mathrm{~m}, 723 \mathrm{w}, 698 \mathrm{~m}$.<smiles>CC(=O)c1c(C)cc(C)oc1=O</smiles>

Chart 3. Structure of $\mathrm{Na}[\mathrm{dha}]$ (numbering refers to carbon atoms). [26]

\subsection{5. $\left[\left(\eta^{6}-p\right.\right.$-cymene $\left.) R u C l\left(\kappa^{2} O, O^{\prime}-a c a c\right)\right], 3[43]$.}

The title compound was prepared as described for $\left[\left(\eta^{6}-p\right.\right.$-cymene $\left.) \mathrm{RuCl}\left(\kappa^{2} O, O^{\prime}-\mathrm{dha}\right)\right]$, using $\left[\left(\eta^{6}-p\right.\right.$ cymene $\left.) \mathrm{RuCl}_{2}\right]_{2}(123 \mathrm{mg}, 0.200 \mathrm{mmol})$, acetyl acetone $(45 \mu \mathrm{L}, 0.44 \mathrm{mmol})$ and $1.0 \mathrm{M} \mathrm{NaOH}(0.45 \mathrm{~mL}$, 
$0.45 \mathrm{mmol}$ ) in $\mathrm{MeOH}(4 \mathrm{~mL})$. Reaction time $=2$ hours. Yield: $123 \mathrm{mg}, 83 \%$ (ocher-yellow solid). Compound 3 is soluble in $\mathrm{MeOH}$ and $\mathrm{CH}_{2} \mathrm{Cl}_{2}$, poorly soluble in $\mathrm{Et}_{2} \mathrm{O}$ and insoluble in hexane. Anal. Calcd. for $\mathrm{C}_{15} \mathrm{H}_{21} \mathrm{ClO}_{2} \mathrm{Ru}$ : C, 48.71; H, 5.72. Found: C, 48.84; H, 5.75. IR (solid state): $\tilde{v} / \mathrm{cm}^{-1}=$ 3066w, 3030w, 2962m, 2918w, 2873w, 1574s ( $\left.v_{\mathrm{C} 10-\mathrm{C} 9-\mathrm{O}}\right), 1521 \mathrm{~s}\left(v_{\mathrm{C} 10-\mathrm{C} 9-\mathrm{O}}\right), 1469 \mathrm{~m}, 1427 \mathrm{~m}, 1386 \mathrm{~s}$, $1324 \mathrm{~m}, 1300 \mathrm{w}, 1269 \mathrm{~m}, 1198 \mathrm{~m}, 1161 \mathrm{w}, 1145 \mathrm{w}, 1115 \mathrm{w}, 1095 \mathrm{~m}, 1055 \mathrm{~m}, 1018 \mathrm{~m}, 932 \mathrm{~m}, 904 \mathrm{w}, 881 \mathrm{~m}$, 794m, 779m-sh, 677w, 657w. ${ }^{1} \mathrm{H}$ NMR $\left(\mathrm{CDCl}_{3}\right): \delta / \mathrm{ppm}=5.43\left(\mathrm{~d},{ }^{3} J_{\mathrm{HH}}=5.9 \mathrm{~Hz}, 2 \mathrm{H}, \mathrm{C} 4-\mathrm{H}\right), 5.18(\mathrm{~d}$, $\left.{ }^{3} J_{\mathrm{HH}}=5.9 \mathrm{~Hz}, 2 \mathrm{H}, \mathrm{C} 3-\mathrm{H}\right), 5.12(\mathrm{~s}, 1 \mathrm{H}, \mathrm{C} 10-\mathrm{H}), 2.84$ (hept, $\left.{ }^{3} J_{\mathrm{HH}}=6.9 \mathrm{~Hz}, 1 \mathrm{H}, \mathrm{C} 6-\mathrm{H}\right), 2.24$ (s, 3H, C1H), $1.96(\mathrm{~s}, 6 \mathrm{H}, \mathrm{C} 8-\mathrm{H}), 1.28\left(\mathrm{~d},{ }^{3} J_{\mathrm{HH}}=6.9 \mathrm{~Hz}, 6 \mathrm{H}, \mathrm{C} 7-\mathrm{H}\right)$.

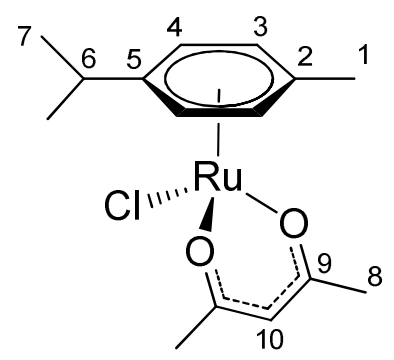

Chart 4. Structure of $\left[\left(\eta^{6}-p\right.\right.$-cymene $) \mathrm{RuCl}\left(\kappa^{2} O, O^{\prime}\right.$-acac) $), 3$ (numbering refers to carbon atoms).

\subsection{Stability of Ru compounds in dmso/water solutions}

4.3.1. General procedure. A stock DMSO- $\mathrm{d}_{6} / \mathrm{D}_{2} \mathrm{O} 9: 1 v / v$ solution containing $\mathrm{NaCl}\left(0.11 \mathrm{~mol} \cdot \mathrm{L}^{-1}\right)$ and dimethyl sulfone $\left(5.6 \cdot 10^{-3} \mathrm{~mol} \cdot \mathrm{L}^{-1}\right)$ as reference for ${ }^{1} \mathrm{H}$ NMR spectra $(\delta / \mathrm{ppm}=2.97(\mathrm{~s}, 6 \mathrm{H})$ in DMSO$\left.\mathrm{d}_{6} / \mathrm{D}_{2} \mathrm{O} 9: 1 v / v\right)$ was used for the following experiments. Complexes $\mathbf{2}$ and $\mathbf{3}$ were dissolved in the DMSO- $\mathrm{d}_{6} / \mathrm{D}_{2} \mathrm{O}$ solution $\left(0.6 \mathrm{~mL} ;[\mathrm{Ru}]=1.5 \cdot 10^{-2} \mathrm{~mol} \cdot \mathrm{L}^{-1}\right)$ and the resulting solution was maintained at $37^{\circ} \mathrm{C}$ for 72 hours and analyzed by ${ }^{1} \mathrm{H}$ NMR spectroscopy as a function of time. Percent values of compounds in solution are based on ${ }^{1} \mathrm{H}$ NMR spectroscopy and refer to identified compounds only (indicated as “\% NMR") or refer to dimethyl sulfone used as internal standard (indicated as " $\% N M R v s$ internal standard"). 
4.3.2. Reference data. NMR spectra of the following compounds dissolved in the $\mathrm{DMSO}-\mathrm{d}_{6} / \mathrm{D}_{2} \mathrm{O}$ solution were recorded and used for comparison for NMR assignments. p-cymene. ${ }^{1} \mathrm{H}$ NMR (DMSO$\left.\mathrm{d}_{6}: \mathrm{D}_{2} \mathrm{O} 9: 1\right): \delta / \mathrm{ppm}=7.12-7.03(\mathrm{~m}, 4 \mathrm{H}), 2.80$ (hept, $\left.J=6.9 \mathrm{~Hz}, 1 \mathrm{H}\right), 2.23(\mathrm{~s}, 3 \mathrm{H}), 1.15(\mathrm{~d}, J=6.9 \mathrm{~Hz}$, 6H). Na[dha] $\cdot \mathbf{H}_{2}$ O. ${ }^{1} \mathrm{H}$ NMR (DMSO-d 6 : $\left.\mathrm{D}_{2} \mathrm{O} 9: 1\right): \delta / \mathrm{ppm}=5.47(\mathrm{~s}, 1 \mathrm{H}), 2.28(\mathrm{~s}, 3 \mathrm{H}), 1.96(\mathrm{~s}, 3 \mathrm{H})$. acacH. ${ }^{1} \mathrm{H}$ NMR (DMSO-d $\left.\mathrm{d}_{6}: \mathrm{D}_{2} \mathrm{O} 9: 1\right): \delta / \mathrm{ppm}=5.68\left(\mathrm{~s}, 0.2 \mathrm{H}^{*}\right), 3.63(\mathrm{~s}, 0.5 \mathrm{H}), 2.10+1.96(\mathrm{~s}, 6 \mathrm{H})$. Na[acac]. ${ }^{1} \mathrm{H}$ NMR (DMSO-d $\left.6: \mathrm{D}_{2} \mathrm{O} 9: 1\right): \delta / \mathrm{ppm}=4.77\left(\mathrm{~s}, 1 \mathrm{H}^{*}\right), 1.65(\mathrm{~s}, 6 \mathrm{H}) .{ }^{*} \mathrm{H} / \mathrm{D}$ exchange with the solvent lowers the integral value. [( $\boldsymbol{\eta}^{6}-\boldsymbol{p}$-cymene) $\left.\mathbf{R u C l}_{2}\right]_{2} \cdot{ }^{1} \mathrm{H}$ NMR $\left(\mathrm{DMSO}-\mathrm{d}_{6}: \mathrm{D}_{2} \mathrm{O} 9: 1\right): \delta / \mathrm{ppm}=$ $5.79(\mathrm{~d}, J=6.3 \mathrm{~Hz}, 2 \mathrm{H}), 5.74(\mathrm{~d}, J=6.3 \mathrm{~Hz}, 2 \mathrm{H}), 2.79$ (hept, $J=6.9 \mathrm{~Hz}, 1 \mathrm{H}), 2.07(\mathrm{~s}, 3 \mathrm{H}), 1.17(\mathrm{~d}, J=$ 6.9 Hz, 6H). This set of signals was attributed to the formation of a solvato-complex $\left[\left(\eta^{6}-p\right.\right.$ cymene) $\left.\mathrm{RuCl}_{2}(\mathrm{Solv})\right], \mathbf{S}[4]$.

4.3.3. Stability studies: compound 2. Red-brown solution $(0-7 \mathrm{~h})$, yellow-brown solution $(7-72 \mathrm{~h})$. Data are reported in Table 4 while NMR detected species are shown in Scheme 4. 2. ${ }^{1} \mathrm{H}$ NMR (DMSO$\left.\mathrm{d}_{6}: \mathrm{D}_{2} \mathrm{O} 9: 1\right): \delta / \mathrm{ppm}=5.90(\mathrm{~s}, 1 \mathrm{H}), 5.74(\mathrm{~d}, J=5.5 \mathrm{~Hz}, 2 \mathrm{H}), 5.47(\mathrm{~d}, J=5.8 \mathrm{~Hz}, 2 \mathrm{H}), 2.77$ (hept, $J=$ $6.7 \mathrm{~Hz}, 1 \mathrm{H}), 2.42(\mathrm{~s}, 3 \mathrm{H}), 2.11(\mathrm{~s}, 3 \mathrm{H}), 2.04(\mathrm{~s}, 3 \mathrm{H}), 1.25(\mathrm{~d}, J=6.9 \mathrm{~Hz}, 6 \mathrm{H})$.

4.3.4. Stability studies: compound 3. Yellow-brown solution. Data are reported in Table 5 while NMR detected species are shown in Scheme 5. 3. ${ }^{1} \mathrm{H}$ NMR (DMSO- $\left.\mathrm{d}_{6}: \mathrm{D}_{2} \mathrm{O} 9: 1\right): \delta / \mathrm{ppm}=5.55(\mathrm{~d}, J=5.9 \mathrm{~Hz}$, 2H), $5.29(\mathrm{~d}, J=5.9 \mathrm{~Hz}, 2 \mathrm{H}), 5.09\left(\mathrm{~s}, 1 \mathrm{H}^{*}\right), 2.70$ (hept, $\left.J=6.7 \mathrm{~Hz}, 1 \mathrm{H}\right), 1.83(\mathrm{~s}, 6 \mathrm{H}), 1.21(\mathrm{~d}, J=6.9$ $\mathrm{Hz}, 6 \mathrm{H}) .{ }^{*} \mathrm{H} / \mathrm{D}$ exchange with the solvent lowers the integral value. Acac-derivative. ${ }^{1} \mathrm{H}$ NMR $\left(\right.$ DMSO $-\mathrm{d}_{6}: \mathrm{D}_{2} \mathrm{O}$ 9:1): $\delta / \mathrm{ppm}=1.75+1.72(\mathrm{~s}, 6 \mathrm{H})$. Other species. ${ }^{1} \mathrm{H}$ NMR $\left(\right.$ DMSO- $\mathrm{d}_{6}: \mathrm{D}_{2} \mathrm{O}$ 9:1): $\delta / \mathrm{ppm}=5.24(\mathrm{~d}), 5.02(\mathrm{~d}), 2.33(\mathrm{~m}), 2.21(\mathrm{~m}), 2.05(\mathrm{~m}), 1.97(\mathrm{~s}), 1.08-1.02(\mathrm{~m})$. 


\subsection{X-ray crystallography.}

Crystal data and collection details for 2 are reported in Table 6. Data were recorded on a Bruker APEX II diffractometer equipped with a PHOTON100 detector using Mo-K $\alpha$ radiation. Data were corrected for Lorentz polarization and absorption effects (empirical absorption correction SADABS) [44]. The structures were solved by direct methods and refined by full-matrix least-squares based on all data using $F^{2}$ [45]. Hydrogen atoms were fixed at calculated positions and refined by a riding model. All non-hydrogen atoms were refined with anisotropic displacement parameters.

\section{Table 6.}

Crystal data and measurement details for 2.

\begin{tabular}{|c|c|}
\hline Formula & $\mathrm{C}_{18} \mathrm{H}_{21} \mathrm{ClO}_{4} \mathrm{Ru}$ \\
\hline FW & 437.87 \\
\hline $\mathrm{T}, \mathrm{K}$ & $100(2)$ \\
\hline$\lambda, \AA$ & 0.71073 \\
\hline Crystal system & Triclinic \\
\hline Space group & $P \overline{1}$ \\
\hline$a, \AA$ & $7.0011(6)$ \\
\hline$b, \AA$ & $9.5431(8)$ \\
\hline$c, \AA$ & $14.1615(12)$ \\
\hline$\alpha,{ }^{\circ}$ & $109.268(2)$ \\
\hline$\beta,{ }^{\circ}$ & $98.744(2)$ \\
\hline$\gamma,{ }^{\circ}$ & $95.998(2)$ \\
\hline Cell Volume, $\AA^{3}$ & $870.57(13)$ \\
\hline $\mathrm{Z}$ & 2 \\
\hline$D_{c}, \mathrm{~g} \cdot \mathrm{cm}^{-3}$ & 1.670 \\
\hline$\mu, \mathrm{mm}^{-1}$ & 1.072 \\
\hline $\mathrm{F}(000)$ & 444 \\
\hline Crystal size, $\mathrm{mm}$ & $0.15 \times 0.13 \times 0.09$ \\
\hline$\theta$ limits, ${ }^{\circ}$ & $1.554-26.997$ \\
\hline Reflections collected & 11305 \\
\hline Independent reflections & $3768\left[R_{\mathrm{int}}=0.0413\right]$ \\
\hline Data / restraints / parameters & $3768 / 0 / 222$ \\
\hline Goodness on fit on $\mathrm{F}^{2}$ & 1.125 \\
\hline$R_{1}(I>2 \sigma(I))$ & 0.0403 \\
\hline$w R_{2}$ (all data) & 0.0736 \\
\hline Largest diff. peak and hole, e $\AA^{-3}$ & $1.030 /-1.232$ \\
\hline
\end{tabular}




\section{Acknowledgements}

We gratefully thank the University of Pisa for financial support (PRA 2017).

Supporting Information. CCDC contain the supplementary crystallographic data for the X-ray study reported in this paper. CCDC 1564132 (2). For ESI and crystallographic data in CIF or other electronic format see DOI: XXXXXXX

\section{References}

[1] Selected references are: (a) C. S. Allardyce, P. J. Dyson, Dalton Trans. 45 (2016) 3201-320. (b) B. S. Murray, M. V. Babak, C. G. Hartinger and P. J. Dyson, Coord. Chem. Rev. 306 (2016) 306, 86-114. (c) A. K. Singh, D. S. Pandey, Q. Xu, P. Braunstein, Coord. Chem. Rev. 270-271 (2014) 31-56. (d) A. A. Nazarov, C. G. Hartinger, P. J. Dyson, J. Organomet. Chem. 751 (2014) 251-260. (e) A. L. Noffke, A. Habtemariam, A. M. Pizarro, P. J. Sadler, Chem. Commun. 48 (2012) 5219-5246. (f) A. Habtemariam, M. Melchart, R. Fernàndez, S. Parsons, I. D. H. Oswald, A. Parkin, F. P. A. Fabbiani, J. E. Davidson, A. Dawson, R. E. Aird, D. I. Jodrell, P. J. Sadler, J. Med. Chem. 49 (2006) 6858-6868.

[2] See for instance: (a) A. Ashraf, M. Hanif, M. Kubanik, T. Seohnel, S. M. F. Jamieson, A. Bhattacharyya, C. G. Hartinger, J. Organomet. Chem. 839 (2017) 31-37. (b) W. Kandioller, E. Balsano, S. M. Meier, U. Jungwirth, S. Göschl, A. Roller, M. A. Jakupec, W. Berger, B. K. Keppler, C. G. Hartinger, Chem. Commun. 49 (2013) 3348-3350. (c) F. Caruso, M. Rossi, A. Benson, C. Opazo, D. Freedman, E. Monti, M. B. Gariboldi, J. Shaulky, F. Marchetti, R. Pettinari, C. Pettinari, J. Med. Chem. 55 (2012) 1072-1081. (d) A. Kurzwernhart, W. 
Kandioller, S. Bächler, C. Bartel, S. Martic, M. Buczkowska, G. Mühlgassner, M. A. Jakupec, H.

- B. Kraatz, P. J. Bednarski, V. B. Arion, D. Marko, B. K. Keppler, C. G. Hartinger, J. Med. Chem. 55 (2012) 10512-10522. (e) I. Berger, M. Hanif, A. A. Nazarov, C. G. Hartinger, R. O. John, M. L. Kuznetsov, M. Groessl, F. Schmitt, O. Zava, F. Biba, V. B. Arion, M. Galanski, M. A. Jakupec, L. Juillerat-Jeanneret, P. J. Dyson, B. K. Keppler, Chem. Eur. J. 14 (2008) 90469057.

[3] (a) E. Păunescu, S. McArthur, M. Soudani, R. Scopelliti, P. J. Dyson, Inorg. Chem. 55 (2016) 1788-1808. (b) A. A. Nazarov, S. M. Meier, O. Zava, Y. N. Nosova, E. R. Milaeva, C. G. Hartinger, P. J. Dyson, Dalton Trans. 44 (2015) 3614-3623. (c) G. Agonigi, T. Riedel, S. Zacchini, E. Păunescu, G. Pampaloni, N. Bartalucci, P. J. Dyson, F. Marchetti, Inorg. Chem. 54 (2015) 6504-6512. (d) W. H. Ang, L. J. Parker, A. De Luca, L. Juillerat-Jeanneret, C. J. Morton, M. Lo Bello, M. W. Parker, P. J. Dyson, Angew. Chem. Int. Ed. 48 (2009) 3854-3857.

[4] L. Biancalana, L. Batchelor, A. De Palo, S. Zacchini, G. Pampaloni, P. J. Dyson, F. Marchetti, Dalton Trans, DOI 10.1039/c7dt02062g.

[5] D. Stíbal, B. Therrien, G. Süss-Fink, P. Nowak-Sliwinska, P. J. Dyson, E. Čermáková, M. Řezáčová, P. Tomšík, J. Biol. Inorg. Chem. 21 (2016) 443-452.

[6] J. Yan, X. Lian Lu, J.-D. Lou, L. Zhang, P.-S. Nong, Y.-L. Feng, M. Gao, J.-J. Yang, Synthesis and Reactivity in Inorganic, Metal-Organic, and Nano-Metal Chemistry 41 (2011) 26-30.

[7] (a) X. Duan, Q. OuWang, G. Jing, N. Tao, Food Control 65 (2016) 8-13; (b) D.S. Rao, M.C. Ganorkar, D.L.S. Rao, V.T. John, Natl. Acad. Sci. Lett. 1 (1978) 402.

[8] (a) M. M. Manas, R. Pleixats, Adv. Heterocycl. Chem. 53 (1992), 1-84; (b) O. Prakash, A. Kumar, S. P. Singh, Heterocycles 63 (2004), 1193-1220; (c) A. A. Fadda, K. M. Elattar, Synth. 
Commun. 46 (2016), 1-30; (c) G. Kumar Gupta, A. Mittal, V. Kumar, Lett. Org. Chem. 11 (2014), 273-286.

[9] (a) A. Banerji, A. K. Siddhanta, Curr. Sci. 49 (1980), 845-847; (b) F. Arndt, Org. Synth. Coll. Vol. 3 (1955), 231.

[10] R. Kaushol, J. Indian Chem. Soc. 23 (1946) 16.

[11] (a) M.-Y. Xi, Z.-Y. Sun, H.-P. Sun, J.-M. Jia,; Z.-Y. Jiang,; L. Tao, M. Ye, X. Yang, Y.-J. Wang, X. Xue, Eur. J. Med. Chem. 66 (2013) 364-371; (b) H. Tabuchi, T. Hamamoto, S. Miki, T. Tejima, A. Ichihara, J. Org. Chem. 59 (1994), 4749-4759.

[12] (a) S. J. Branch, Preparation of dehydroacetic acid, US2849456 A (1958); (b) J. T. Fitzpatrick, W. R. Van der Hoeven, Preparation of dehydroacetic acid, US3483224 A (1969); (c) R. Miller, C. Abaecherli, A. Said, B. Jackson, Ketenes. Ullmann's Encyclopedia of Industrial Chemistry, Wiley-VCH Verlag GmbH \& Co.(2001); (b) R. J. Clemens. Diketene. e-EROS Encyclopedia of Reagents for Organic Synthesis, John Wiley \& Sons, Ltd (2001).

[13] (a) J. H. Jensen, E. S. Painter, R. C. Petrey, Pyrolysis process and apparatus for manufacture of ketenes and anhydrides, US3403181 A (1968); (b) J. H. Jensen, E. S. Painter, R. C. Petrey, Apparatus for manufacturing ketenes, US3259469 A (1966); (c) A. Sturzenegger, Preparation of ketene, US2863922 A (1958); (d) G. H. Reid, Process and apparatus for making ketene, US1975663 A (1934).

[14] (a) M. L. Nakashige, R. S. Lewis, W. J. Chain, Tetrahedron Lett. 56 (2015), 3531-3533; (b) J. C. Sauer, J. Am. Chem. Soc., 69 (1947), 2444-2448.

[15] The predominant tautomeric structure of dehydroacetic acid is shown, as ascertained both in chloroform solution and in the solid state (NMR, X-ray). (a) M. Z. Chalaça, J. D. FigueroaVillar, J. Mol. Struct. 554 (2000) 225-231; (b) V. Bertolasi, P. Gilli, V. Ferretti, G. Gilli, J. Chem. Soc., Perkin Trans. 2 (1997), 945-952. 
[16] Recent references include: (a) R. K. Dieter, Tetrahedron 55 (1999), 4177-4236; (b) A. C. B. Burtoloso, R. M. P. Dias, B. Bernardim, Accounts of Chemical Research 48 (2015), 921-934; (c) L. Chi, D. W. C. MacMillan, J. Am. Chem. Soc. 137 (2015), 11938-11941; (d) C.-J. Lee, C.-C. Tsai, S.-H. Hong, G.-H. Chang, M.-C. Yang, L. Moehlmann, W. Lin, Angew. Chem. Int. Ed. 54 (2015), 8502-8505; (e) D. Heift, Z. Benko, R. Suter, R. Verel, H. Grutzmacher, Chem.1 Sci. 7 (2016), 6125-6131; (f) L. Wang, Y.-B. Xie, N.-Y. Huang, J.-Y. Yan, W.-M. Hu, M-.G. Liu, M.-W. Ding, ACS Catalysis 6, (2016), 4010-4016; (g) R. Cookson, T. N. Barrett, A. G. M. Barrett, Acc. Chem. Res. 48 (2015), 628-642.

[17] (a) G. Sartori, G. Casnati, F. Bigi, D. Baraldi, Tetrahedron Lett. 32 (1991), 2153-2156; (b) G. Sartori, F. Bigi, D. Baraldi, R. Maggi, G. Casnati, X. Tao, Synthesis, 1993, 851-852.

[18] (a) G. A. Olah, E. Zadok, R. Edler, D. H. Adamson, W. Kasha, G. K. S. Prakash, J. Am. Chem. Soc. 111 (1989), 9123-9124; (b) J. Schmitt, M. Suquet, J. Boitard, P. Comoy, Compt. Rend. 240 (1955), 2538-2540.

[19] (a) R. Pettinari, A. Petrini, F. Marchetti, C. Pettinari, T. Riedel, B. Therrien and P. J. Dyson, Eur. J. Inorg. Chem. (2017) 1800-1806. (b) J. Palmucci, F. Marchetti, R. Pettinari, C. Pettinari, R. Scopelliti, T. Riedel, B. Therrien, A. Galindo, P. J. Dyson, Inorg. Chem. 55 (2016) 11770 11781. (c) R. Pettinari, F. Marchetti, A. Petrini, C. Pettinari, G. Lupidi, P. Smoleński, R. Scopelliti, T. Riedel, P. J. Dyson, Organometallics 35 (2016) 3734-3742. (d) A. Ashraf, M. Kubanik, F. Aman, H. Holtkamp, T. Söhnel, S. M. F. Jamieson, M. Hanif, W. A. Siddiqui, C. G. Hartinger, Eur. J. Inorg. Chem. (2016) 1376-1382. (e) J. Kljun, A. K. Bytzek, W. Kandioller, C. Bartel, M. A. Jakupec, C. G. Hartinger, B. K. Keppler, I. Turel, Organometallics 30 (2011) $2506-2512$. 
[20] (a) D. Amel, B.Abderrahmen, S.Bouacida, B.Adel, D.Tahar, Acta Cryst. E 62 (2006), m133m135; (b) A. Bouchama, A. Bendaas, C. Chiter, A. Beghidja, A. Djedouani, Acta Cryst. E 63 (2007) $\mathrm{m} 2397$.

[21] J. Casabo, J. Marquet, M. Moreno-Manas, M. Prior, F. Teixidor, Polyhedron 6 (1987), 12351238

[22] M. Z. Chalaca, J. D. Figueroa-Villar, J. A. Ellena, E. E. Castellano, Inorg. Chim. Acta 328, (2002) 45-52

[23] (a) Wen-Yuan Hsieh, C.M.Zaleski, V.L.Pecoraro, P.E.Fanwick, Shuang Liu, Inorg. Chim. Acta 359 (2006), 228-236; (b) M. I. Fernandez, M. Fondo, A. M. Garcia-Deibe, B. Fernandez, M. J. Rodriguez, M. R.Bermejo, Transition Met.Chem. 27 (2002), 416-422; (c) R. E. Marsh, Acta Cryst. B. 60 (2004) 252-253.

[24] A. Djedouani, S. Boufas, A. Bendaas, M. Allain, G. Bouet, Acta Cryst. E 65 (2009), m1205m1206.

[25] H. Luo, S. Liu, S. J. Rettig, C. Orvig, Can. J. Chem. 73 (1995) 2272-2281.

[26] X. Zhang, Q. Yin, W. Du, J. Gong, Y. Bao, M. Zhang, B. Hou, H. Hao, Ind. Eng. Chem. Res. 54 (2015), 3438-3444.

[27] R. Fernández, M. Melchart, A. Habtemariam, S. Parsons, P. J. Sadler, Chem. Eur. J. 10 (2004), $5173-5179$.

[28] (a) Marcus, E.; Chan, John K. J. Org. Chem. 32 (1967) 2881-2886; (b) A. B. Steele, A. B. Boese, M. F. Dull, J. Org. Chem. 14 (1949) 460-469.

[29] a) N. Chitrapriya, V. Mahalingam, M. Zeller, R. Jayabalan, K. Swaminathan, K. Natarajan, Polyhedron 27 (2008) 939-946; (b) K. Yamada, Bull. Chem. Soc. Jap. 35 (1962) 1323-1329.

[30] SDBSWeb : http://sdbs.db.aist.go.jp (National Institute of Advanced Industrial Science and Technology, 02/07/17) 
[31] (a) B. B: Park, N. H. Lee, Y. H. Kim, Y. G. Jae, S. Choi, N. N. Kang, Y. R. Hong, K. Ok, J. Cho,Y. H. Jeon, ChemMedChem 12 (2017), 477-482. (b) J. Devi, S. Devi, A. Kumar, Heteroatom Chem., 27 (2016), 361-371.

[32] E.-H. Pommer, G. Scheuerer, Fungicides for plant protection, US3491189 A (1970).

[33] N. Chitrapriya, V. Mahalingam, M. Zeller, R. Jayabalan, K. Swaminathan, K. Natarajan, Polyhedron 27 (2008), 939-946.

[34] L. Rao, J. Kimler, L. K. Hall, Salts of Dehydroacetic Acid as an Antimicrobial for Plastics, US 20090203812 A1 (2009)

[35] W. Kandioller, A. Kurzwernhart, M. Hanif, S. M. Meier, H. Henke, B. K. Keppler, C. G. Hartinger, J. Organomet. Chem. 696 (2011) 999-1010 and references therein.

[36] a) H. P. Varbanov, D. Ortiz, D. Höfer, L. Menin, M. Galanski, B. K. Keppler, P. J. Dyson, Dalton Trans. 46 (2017) 8929-8932. b) M. Patra, T. Joshi, V. Pierroz, K. Ingram, M. Kaiser, S. Ferrari, B. Spingler, J. Keiser, G. Gasser, Chem. Eur. J. 19 (2013) 14768-14772.

[37] See for instance: (a) F. Aman, M. Hanif, M. Kubanik, A. Ashraf, T. Sçhnel, S. M. F. Jamieson, W. A. Siddiqui, C. G. Hartinger, Chem. Eur. J. 23 (2017) 4893-4902. (b) R. Pettinari, F. Marchetti, C. Pettinari, A. Petrini, R. Scopelliti, C. M. Clavel, P. J. Dyson, Inorg. Chem. 53 (2014) 13105-13111.

[38] S. Seršen, J. Kljun, K. Kryeziu, R. Panchuk, B. Alte, W. Körner, P. Heffeter, W. Berger, I. Turel, J. Med. Chem. 58 (2015) 3984-3996.

[39] A. F. A. Peacock, M. Melchart, R. J. Deeth, A. Habtemariam, S. Parsons, P. J. Sadler, Chem. Eur. J. 13 (2007) 2601-2613.

[40] M. A. Bennett, A. K. Smith, J. Chem. Soc., Dalton Trans. (1974) 233-241.

[41] H. E. Gottlieb, V. Kotlyar, A. Nudelman, J. Org. Chem. 62 (1997) 7512-7515.

[42] W. Willker, D. Leibfritz, R. Kerssebaum, W. Bermel, Magn. Reson. Chem. 31 (1993) 287-292. 
[43] (a) C. A. Vock, A. K. Renfrew, R. Scopelliti, L. Juillerat-Jeanneret, P. J. Dyson, Eur. J. Inorg. Chem. (2008) 1661-1671; (b) K. Sarjit Singh, K. A. Kreisel, G. P. A. Yap, M. Rao Kollipara, J. Organomet. Chem. 691 (2006) 3509-3518.

[44] G. M. Sheldrick, SADABS-2008/1 - Bruker AXS Area Detector Scaling and Absorption Correction, Bruker AXS: Madison, Wisconsin, USA, 2008

[45] G. M. Sheldrick, Acta Crystallogr. C 71 (2015), 3. 
